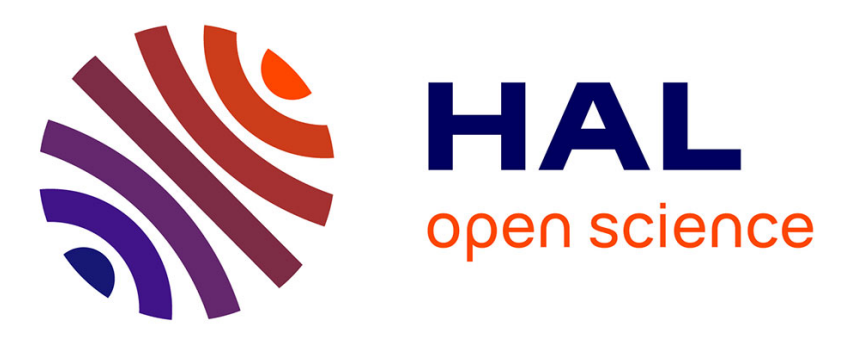

\title{
Dynamic Vehicle Emissions Reduction with Technical and Behavioral Approach
}

Mohammad Syafrizal, Bambang Sugiarto, Setyo Sarwanto Moersidik, Jérôme Fortin, Nadia Hamani, Estelle Bretagne

\section{- To cite this version:}

Mohammad Syafrizal, Bambang Sugiarto, Setyo Sarwanto Moersidik, Jérôme Fortin, Nadia Hamani, et al.. Dynamic Vehicle Emissions Reduction with Technical and Behavioral Approach. International Journal of Technology Management, 2016, 7 (5), pp.871-880. 10.14716/ijtech.v7i5.534 . hal01841864

\section{HAL Id: hal-01841864 \\ https://hal.science/hal-01841864}

Submitted on 19 Jul 2018

HAL is a multi-disciplinary open access archive for the deposit and dissemination of scientific research documents, whether they are published or not. The documents may come from teaching and research institutions in France or abroad, or from public or private research centers.
L'archive ouverte pluridisciplinaire HAL, est destinée au dépôt et à la diffusion de documents scientifiques de niveau recherche, publiés ou non, émanant des établissements d'enseignement et de recherche français ou étrangers, des laboratoires publics ou privés. 


\title{
DYNAMIC VEHICLE EMISSIONS REDUCTION WITH TECHNICAL AND BEHAVIORAL APPROACH
}

\author{
Mohammad Syafrizal $^{*}{ }^{*}$, Bambang Sugiarto ${ }^{1}$, Setyo Sarwanto Moersidik ${ }^{1}$, Jérome Fortin ${ }^{2}$, Nadia \\ Hamani $^{2}$, Estelle Bretagne ${ }^{2}$ \\ ${ }^{1}$ Department of Mechanical Engineering, Faculty of Engineering, Universitas Indonesia, Kampus \\ Baru UI Depok, Depok 16424, Indonesia \\ ${ }^{2}$ University of Picardie Jules Verne, Bat. "Ecole des minimes". 33, rue St Leu. 80039 AMIENS \\ CEDEX
}

(Received: September 2014 / Revised: December 2015 / Accepted: January 2016)

\begin{abstract}
This paper describes the case study of Semanggi intersection in Jakarta, a dynamic model of emission reduction in the land transportation sector. The urban transportation system is a complex system with multiple variables, feedback loops, and is influenced by social, economic and environmental factors. The proposed model consists of two submodels: Vehicle Fleet and Emission Calculation. The model runs in Powersim Studio software using data from the Indonesia Japan Economic Partnership Agreement, and the Traffic Management Centre of the Indonesian National Police. The test was conducted by developing two scenarios: Business As Usual and Intention. The estimated results to be obtained using the first scenario in 2021 should be $1,113,398$ units, while the second scenario is estimated to produce 850,733 units. We hypothesize that the Intentional Approach will have a more significant impact than the Technical Approach, which requires more investment. The Intentional Approach is designed to improve the intention of private car users to switch to public transportation. The Technical Approach to the emission measurement of every vehicle in a certain area is the data of vehicle emission which are usually taken to determine the current condition. This research will no doubt have a positive impact on emission reduction in Jakarta.
\end{abstract}

Keywords: Behavior; Dynamic model; Emission; Jakarta; Road transport

\section{INTRODUCTION}

Jakarta, the largest city in Indonesia, is among the fastest-growing and most polluted cities in the world. Experts estimate that Jakarta would experience total transportation gridlock in 2014, but until early 2016 it has not happened. TransJakarta is the name of the bus rapid transit (BRT) system in Jakarta that started in 2004. TransJakarta buses carry 315,000 people each day, and the number is expected to double as new buses hit the streets by the end of 2013 (The Jakarta Post, 2013). According to hourly video traffic assessment and manual counts on Semanggi, a famous road in Jakarta, daily traffic volume might be greater than 385,000 vehicles (IJ-EPA 2009-2011).

A recent article shows that carbon dioxide ( $\mathrm{CO}$ for short) and particle matter PM2.5 on-road exposure was greater for private car commuters than for public transport commuters (Adam, 2013). This paper develops a system dynamics model to produce in emissions estimates from

*Corresponding author's email: msyafrizal@yahoo.com, Tel. +62-21-3506144, Fax. +62-21-3506143

Permalink/DOI: http://dx.doi.org/10.14716/ijtech.v7i5.534 
2011 to 2021 in a case study of the Semanggi intersection. This paper compares emissions obtained for two different scenarios: the Business as Usual (BAU) scenario and the Intention Scenario, beginning in 2011 and with 2021 as the target year.

The BAU scenario represents no improvement in the public transportation service, and predicts how emission from certain activity sectors will develop in the absence of additional technical and non-technical control (Lumbreras et al., 2015). This scenario, we assume that vehicle technology remains at the current level and no new policy is made to limit vehicle numbers over the next 10 years.

The Intention Scenario considers some improvements in the road transport sector if private vehicle users change to public transportation (such as TransJakarta). It attempts to understand the behavior of car owners according to the theory of planned behavior (TPB), a framework of psychological factors underlying public transportation use (Ajzen, 1988; Ajzen, 1991), using research on BRT use in Jakarta from Hafiyah and Sesetyo (2011) and Sugiarto et al. (2010) to build a system dynamics model for gathering data.

\section{EXPERIMENTAL METHODOLOGY}

System dynamics (SD) was introduced by Jay Forrester in the 1950s and is a well-established simulation methodology for understanding, visualizing and analyzing complex dynamic feedback systems (Zhao et al., 2011). The aim of SD modeling is to learn and understand delays in structure, policy and decision making. There are four common stages in the methodology: model conceptualization, formulation, validation and scenario analysis.

Figure 1 describes that the demand for transportation will influence all transportation mode demands and increased demand will raise emissions levels, which, in turn, will affect health quality. The impact on health will reduce life expectancy and slow the population growth. The decrease in population growth will reduce the growth of transportation demand. The base years (2011 and 2021) are set as the target years.

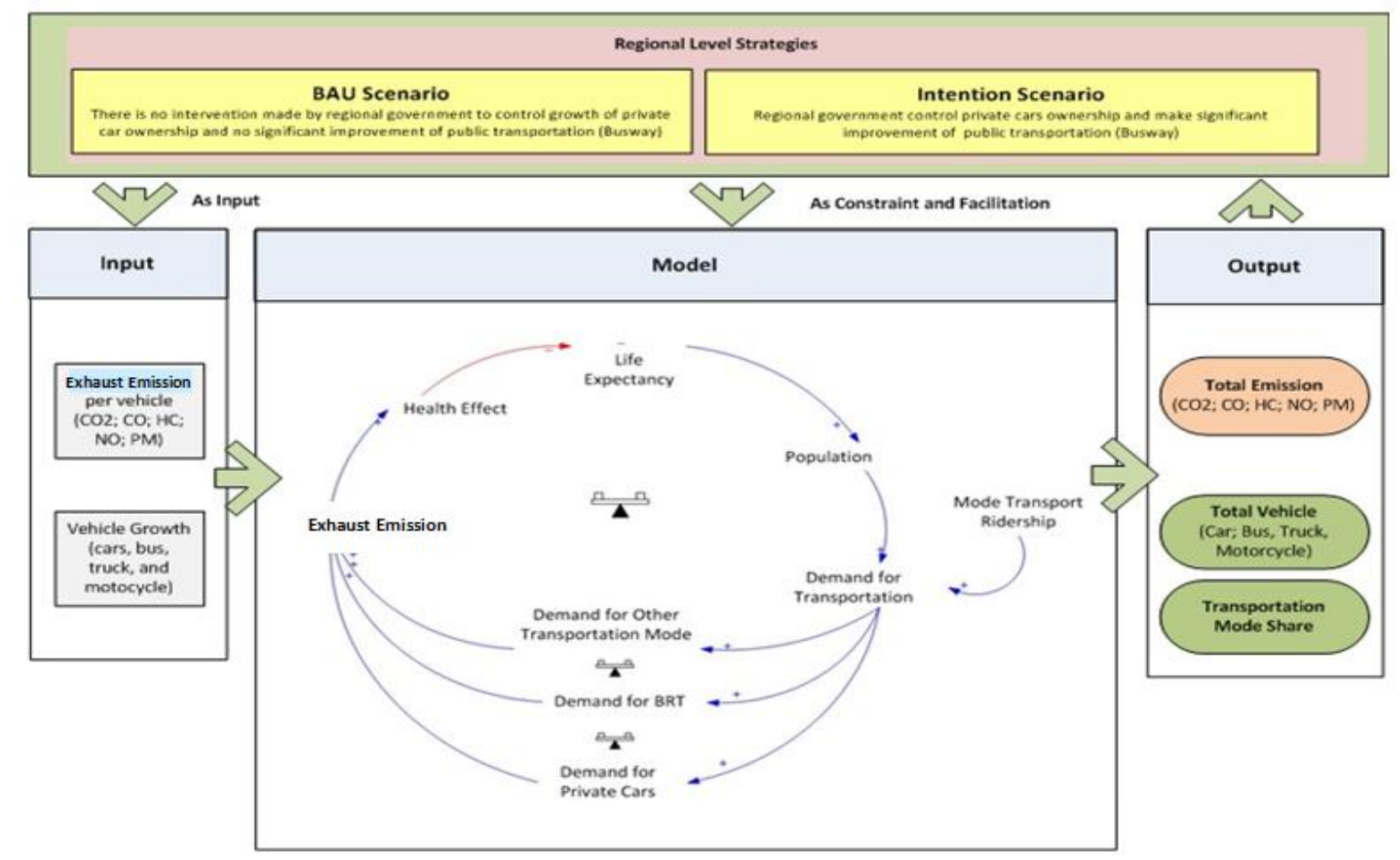

Figure 1 Model conceptualization 
In the BAU Scenario, emissions are projected as if there is no significant increase in public transportation use. The Intention Scenario highlights potential emission reduction by convincing private automobile owners to use the BRT. The impacts of both scenarios are compared in terms of the number of vehicles and exhaust emission indicators.

This research was conducted using surveys to obtain initial data, from which the base model was made to establish the simulation. The results provide a conceptual model that will be developed into a framework that logically demonstrates a causal relationship among the related factors. The final model consists of input variables, model processes, output indicators and policy options, as shown in Figure 1. Regional governments have two plausible policies to fulfill their objectives at the Semanggi Intersection. In the model, government intervention will directly affect the endogenous structure, which is represented by a Causal Loop Diagram (CLD).

\section{RESULTS}

The model structure (Figures 2 to 5) presents vehicle fleed number and exhaust emissions $\left(\mathrm{CO}, \mathrm{HC}, \mathrm{NOx}, \mathrm{PM}\right.$, and $\mathrm{CO}_{2}$ ) related to the public vehicle fleet. Dynamics of the system are defined by the structure and the interaction of components.

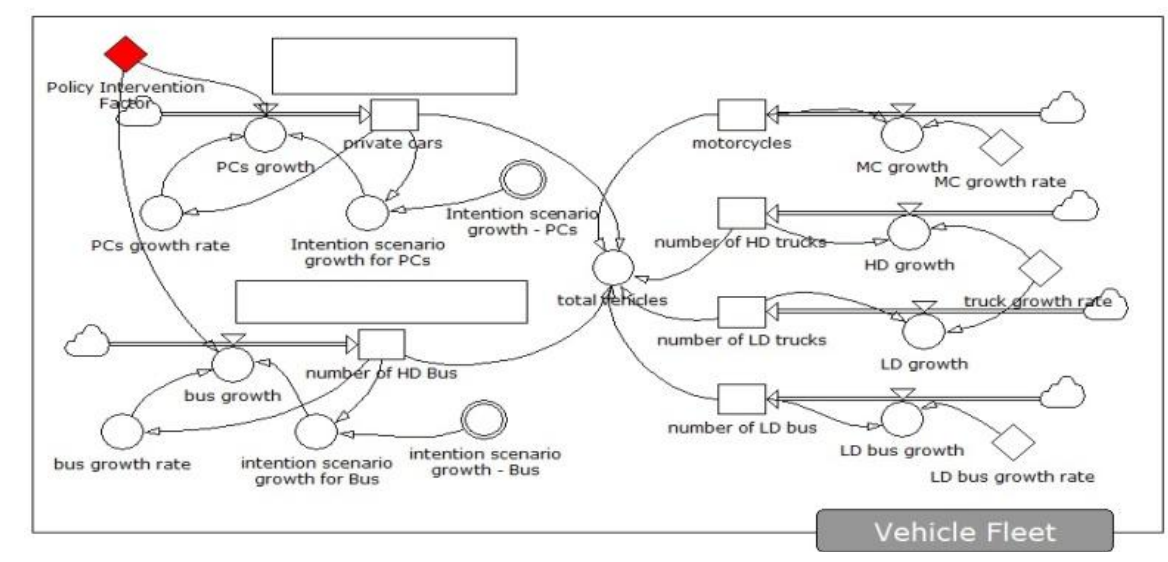

Figure 2 Model structure of vehicle fleet module

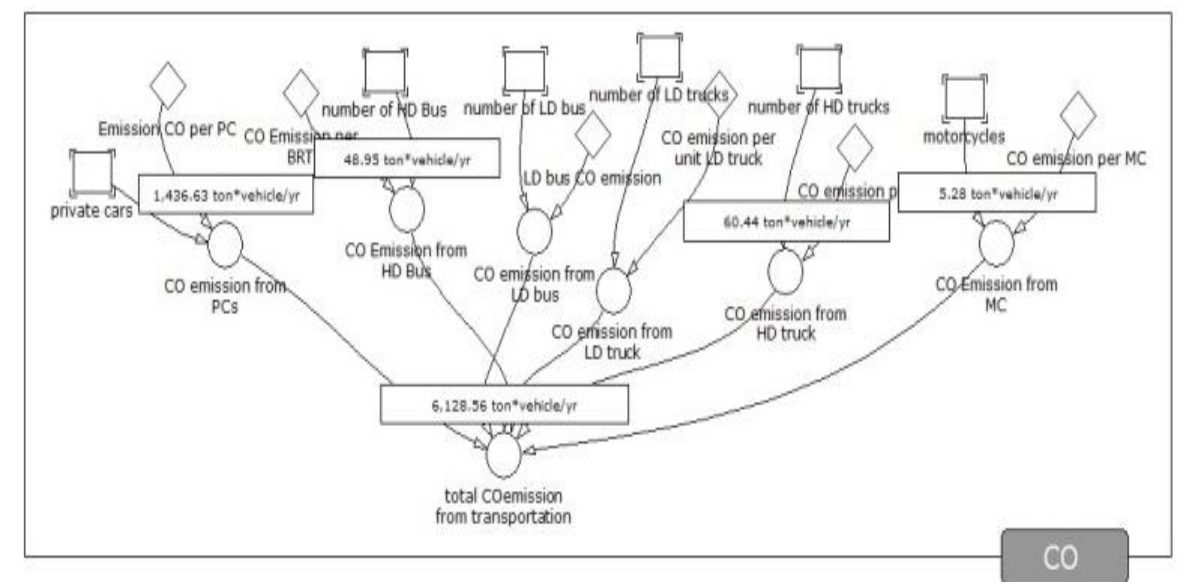

Figure 3 Model structure of emissions calculation module for CO 


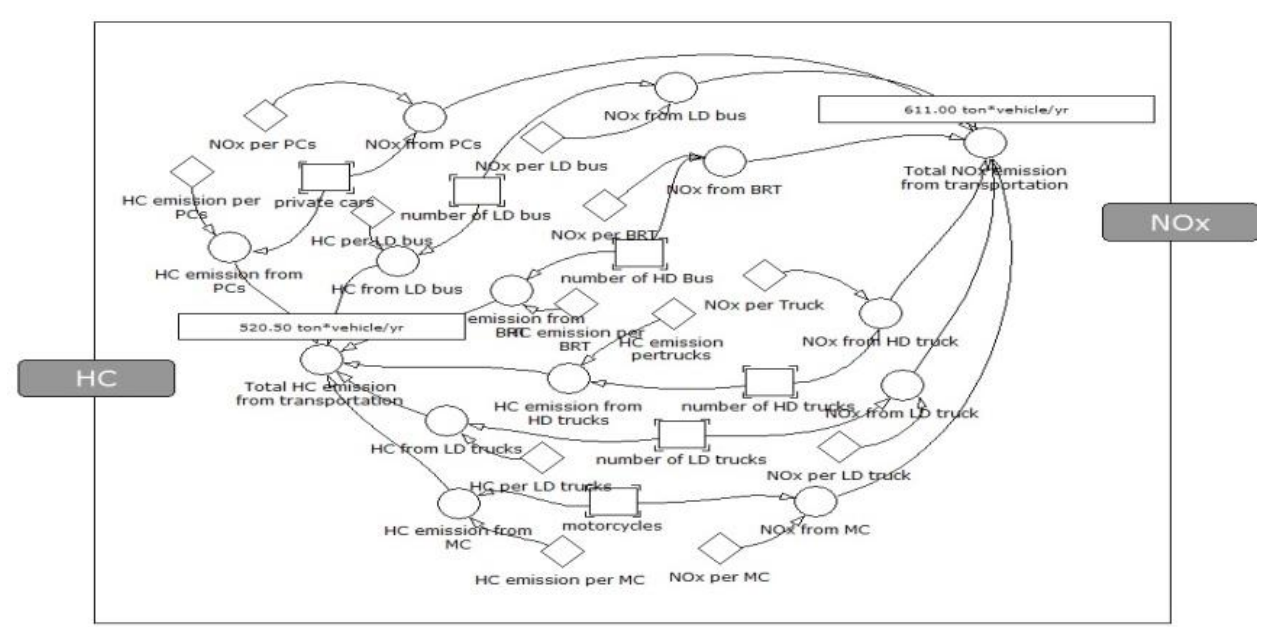

Figure 4 Model structure of emissions calculation module for $\mathrm{HC}$ and Nox

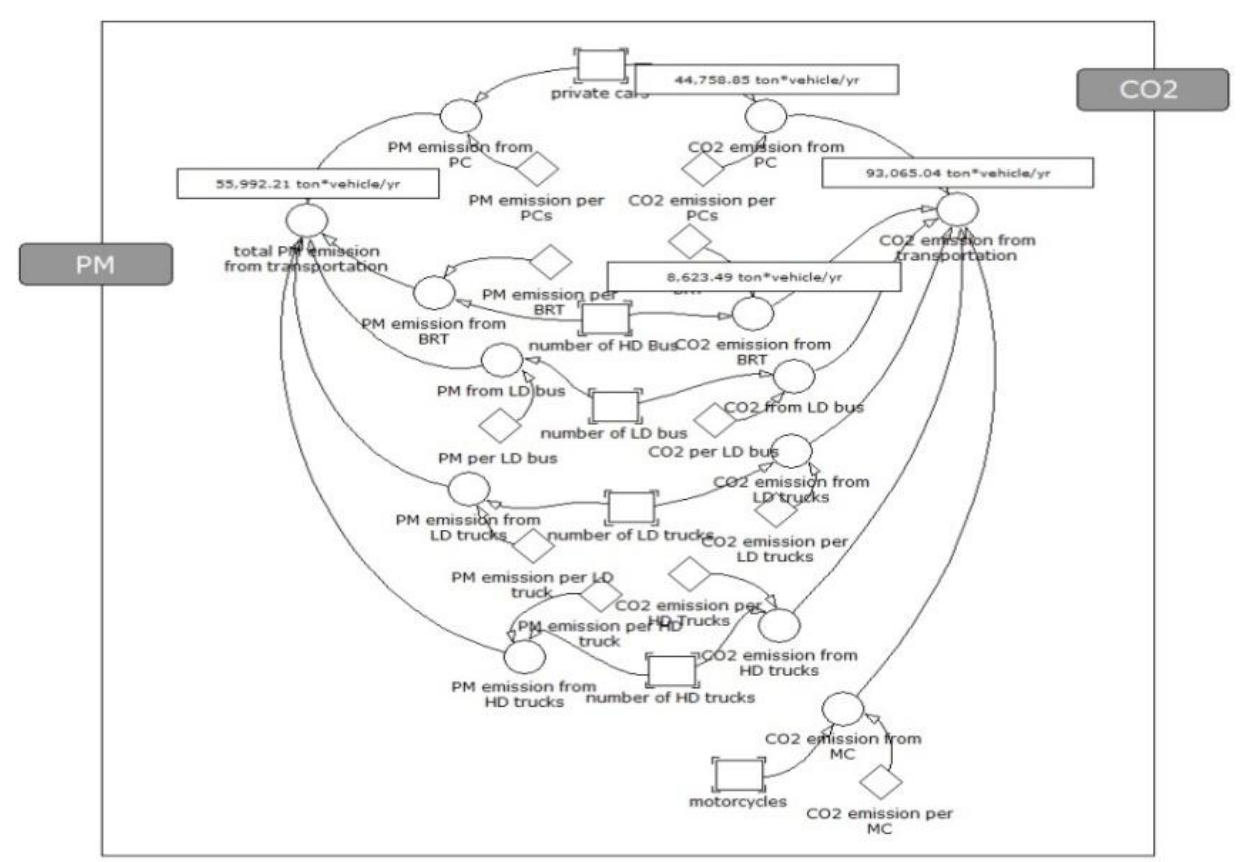

Figure 5 Model structure of emissions calculation module for $\mathrm{PM}$ and $\mathrm{CO}_{2}$

\subsection{Input Model}

The input model was built by calculating emissions and factors described in the previous chapters. Emission parameters consist of $\mathrm{CO}, \mathrm{HC}, \mathrm{NOx}, \mathrm{CO}_{2}$, and $\mathrm{PM}$. Both repartition and the number of vehicles consist of data or simulation based on National Police Headquarters data (2013).

Vehicles include various types: passenger cars, buses, trucks and motorcycles. Passenger cars consist of gasoline and diesel cars. Each type of passenger car is divided into Euro-II and nonEuro type (Table 1) standards. Buses consist of two size types: heavy-duty and light-duty. Each type of bus is divided into Euro-II and Non-Euro (Table 2) standards. Trucks consist of two size types: heavy-duty truck and light-duty truck. Each type of truck is divided into Euro-II and non-Euro (Table 3) standards. Motorcycles consist of two engine types: four-stroke (Euro-II) and two-stroke (non-Euro) (Table 4). The vehicle data in Jakarta (2010-2012) are shown in Table 5. Growth of passenger cars is about $9.85 \%$. 
The data of vehicle number were taken in 2009-2011 (Syafrizal, 2014) and the research results showed that private car owners expected the improvement of services (comfort and safety) of BRT TransJakarta. This improvement started in the period from 2011 until 2015. BRT TransJakarta in 2015 was already comfortable and safe in terms of the desirability of private vehicle users. If this condition occured, then there would be movement of passengers from private cars to BRT TransJakarta of about $67.8 \%$, according to research by Hafiyah and Soesetyo (2011).

This paper divides vehicles into two types, based on the fuel type and emission regulation, to more closely resemble the real condition of Jakarta's transportation sector. Passenger cars are divided based on diesel cars (8\%) and gasoline cars (92\%), while for emission regulation, they are divided into Non-Euro (10\%) and Euro-II (90\%). Heavy duty trucks/buses and light duty trucks/buses all use diesel fuel (100\%) and for emission regulation are divided into Non-Euro and Euro-II, (70\% and 30\%, respectively). Motorcycles all use gasoline (100\%), while for stroke, they are divided into four-stroke (Euro-II) and two-stroke (Non-Euro) (95\% and 5\%, respectively).

Table 1 Assumption of $\mathrm{CO}$ emissions for passenger cars.

Average growth of passenger cars: 0.1891 (19\%)

\begin{tabular}{|c|c|c|c|c|c|c|c|}
\hline 0.1891 & $\begin{array}{c}\text { Repartition } \\
(\%)\end{array}$ & Fuel & Гуре & $\begin{array}{c}\text { Repartition } \\
(\%)\end{array}$ & $\begin{array}{c}\text { CO Emissions } \\
\text { (ton/day) }\end{array}$ & Number & $\begin{array}{c}\text { CO Emissions per } \\
\text { Unit }\end{array}$ \\
\hline \multirow{5}{*}{ 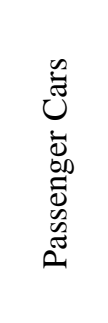 } & \multirow{2}{*}{$92 \%$} & \multirow{2}{*}{$\begin{array}{c}\text { Gasoli } \\
\text { ne }\end{array}$} & Euro 2 & $90 \%$ & 2.05845 & 182,082 & 0.000021616 \\
\hline & & & $\begin{array}{l}\text { Non } \\
\text { Euro }\end{array}$ & $10 \%$ & 1.45378 & & 0.007889991 \\
\hline & \multirow[b]{2}{*}{$8 \%$} & \multirow[b]{2}{*}{ Diesel } & Euro 2 & $90 \%$ & 0.01922 & & \\
\hline & & & $\begin{array}{l}\text { Non } \\
\text { Euro }\end{array}$ & $10 \%$ & 0.40451 & & \\
\hline & $100 \%$ & & Total & & 3.93596 & & \\
\hline
\end{tabular}

Table 2 Assumption of $\mathrm{CO}$ emissions for buses.

Average growth of buses: 0.0251 (2.5\%)

\begin{tabular}{|c|c|c|c|c|c|c|c|c|}
\hline 0.0251 & $\%$ & Fue & Type & & $\begin{array}{l}\text { CO Emissions } \\
\text { (ton/day) }\end{array}$ & Number & CO Emissior & per Unit \\
\hline \multirow{5}{*}{$\begin{array}{l}\mathscr{D} \\
\stackrel{\mathscr{D}}{\vec{n}} \\
0\end{array}$} & \multirow{4}{*}{$\begin{array}{l}\bar{D} \\
\stackrel{0}{0} \\
\stackrel{0}{0}\end{array}$} & \multirow{2}{*}{ HD Bus } & Euro 2 & $90 \%$ & 0.02568 & \multirow{2}{*}{6,196} & 0.00002164 & ton/day \\
\hline & & & Non Euro & $10 \%$ & 0.10842 & & 0.00789969 & ton/year \\
\hline & & \multirow{2}{*}{ LD Bus } & Euro 2 & $90 \%$ & 0.00820 & \multirow{2}{*}{4,531} & 0.00000564 & ton/day \\
\hline & & & Non Euro & $10 \%$ & 0.01735 & & 0.00205821 & ton/year \\
\hline & & & & & 0.15965 & & & \\
\hline
\end{tabular}

Table 3 Assumption of $\mathrm{CO}$ emissions for trucks.

Average growth of trucks: 0.0390 (3\%)

\begin{tabular}{|c|c|c|c|c|c|c|c|c|}
\hline 0.0390 & $\%$ & Fuel & Гуре & & $\begin{array}{l}\text { CO Emissions } \\
\text { (ton/day) }\end{array}$ & Number & Emissions & er Unit \\
\hline \multirow{5}{*}{$\underset{E}{\frac{n}{e}}$} & \multirow{4}{*}{$\begin{array}{l}\overline{\mathcal{D}} \\
\stackrel{\mathscr{\omega}}{\Delta} \\
\stackrel{0}{0}\end{array}$} & \multirow{2}{*}{ HD Truck } & Euro 2 & $30 \%$ & 0.04692 & \multirow{2}{*}{14,811} & 0.00001118 & ton/day \\
\hline & & & Non Euro & $70 \%$ & 0.11867 & & 0.00408077 & ton/year \\
\hline & & \multirow{2}{*}{ LD Truck } & Euro 2 & $30 \%$ & 0.04207 & \multirow{2}{*}{25,800} & 0.00000485 & ton/day \\
\hline & & & Non Euro & $70 \%$ & 0.08308 & & 0.00177053 & ton/year \\
\hline & & & & & 0.29074 & & & \\
\hline
\end{tabular}


Table 4 Assumption of $\mathrm{CO}$ emissions for motorcycles.

Average growth of motorcycles: $0.7359(73 \%)$

\begin{tabular}{|c|c|c|c|c|c|c|c|}
\hline 0.7359 & $\%$ & \multicolumn{2}{|c|}{ Fuel Type } & \multirow{2}{*}{$\begin{array}{c}\text { CO Emissions } \\
\text { (ton/day) }\end{array}$} & \multirow{2}{*}{$\begin{array}{c}\text { Number } \\
152,014\end{array}$} & \multicolumn{2}{|c|}{ CO Emission per Unit } \\
\hline \multirow{3}{*}{ 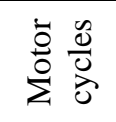 } & $95 \%$ & Strokes 4 & Euro 2 & & & 0.000034710 & ton/day \\
\hline & $5 \%$ & Strokes 2 & Non Euro & 0.08113 & & & \\
\hline & & & & 5.27642 & & & \\
\hline
\end{tabular}

Table 5 Total number of vehicles 2010-2012

\begin{tabular}{ccccccc}
\hline Year & $\begin{array}{c}\text { Passenger } \\
\text { Cars }\end{array}$ & Buses & Trucks & Motorcycles & $\begin{array}{c}\text { Special } \\
\text { vehicles }\end{array}$ & $\begin{array}{c}\text { Total } \\
\text { Vehicles }\end{array}$ \\
\hline 2010 & $2,296,055$ & 329,559 & 464,730 & $8,764,107$ & 143,068 & $11,997,519$ \\
2011 & $2,502,501$ & 332,179 & 507,685 & $9,861,423$ & 144,014 & $13,347,802$ \\
2012 & $2,770,282$ & 337,635 & 593,066 & $10,862,476$ & 147,752 & $14,711,211$ \\
\hline
\end{tabular}

Source: National Police Headquarters (data processed), 2011

\section{DISCUSSION}

\subsection{Output Model}

4.1.1. Business as usual scenario

Vehicle fleet data are taken from 2010 to 2012 (National Police Headquarters Indonesia, 2015 (Table 5). Then, the data are simulated for a target of 2021 (Table 6) regarding the Semanggi intersection, one of the busiest intersection in Jakarta (weekday traffic volume in both toll and non-toll roads). The total number of vehicles was 385,434 units in 2011 and this figure is expected to be 1,113,398 units in 2021. The vehicle graph BAU scenario is shown in Figure 6a. The highest number of vehicles includes passenger cars (182,082 units in 2011 and 484,658 units in 2021) and motorcycles (152,014 units in 2011 and 468,722 in 2021). The data shown in Table 6 is the simulated result of predicted vehicle growth rate using Powersim Software. However, if compared to the growth rate of each kind of vehicles, Light Duty (LD) trucks and Heavy Duty (HD) trucks have the highest percentage.

Table 6 Vehicle fleet with BaU scenario: weekday traffic volume in toll and non-toll roads of Semanggi intersection

\begin{tabular}{lccccccr}
\hline BAU & Passenger Cars & HD Buses & LD Buses & HD Trucks & LD Trucks & Motorcycles & Total \\
\hline 2011 & 182,082 & 6,196 & 4,531 & 14,811 & 25,800 & 152,014 & 385,434 \\
2012 & 200,809 & 6,272 & 4,587 & 16,855 & 29,360 & 170,132 & 428,014 \\
2013 & 221,463 & 6,349 & 4,643 & 19,180 & 33,411 & 190,410 & 475,455 \\
2014 & 244,240 & 6,427 & 4,700 & 21,826 & 38,020 & 213,105 & 528,319 \\
2015 & 269,361 & 6,506 & 4,757 & 24,838 & 43,266 & 238,504 & 587,232 \\
2016 & 297,065 & 6,585 & 4,816 & 28,265 & 49,236 & 266,931 & 652,898 \\
2017 & 327,618 & 6,666 & 4,875 & 32,165 & 56,029 & 298,746 & 726,100 \\
2018 & 361,314 & 6,748 & 4,935 & 36,603 & 63,760 & 334,354 & 807,713 \\
2019 & 398,475 & 6,831 & 4,995 & 41,653 & 72,557 & 374,205 & 898,716 \\
2020 & 439,459 & 6,914 & 5,056 & 47,400 & 82,568 & 418,806 & $1,000,204$ \\
2021 & 484,658 & 6,999 & 5,118 & 53,940 & 93,961 & 468,722 & $1,113,398$ \\
\hline
\end{tabular}

Source: IJ EPA (2011)

\subsubsection{Intention scenario}

The vehicle fleet in this scenario is shown in Table 7. The total number of vehicles in 2011 was 385,434 units and in 2021 it is projected to be 850,733 units. The data was obtained in 2011 however they are still valid because the transportations condition is still the same. The vehicle 
graph of the Intention Scenario is shown in Figure 6b. The highest number of vehicles included passenger cars (182,082 units in 2011 and 219,865 units expected in 2021) and motorcycles (152,014 units in 2011 and 468,722 expected in 2021). Notably, in 2015 the number of passenger cars was projected to decrease from 244.240 units (2014) to 119.086 units (2015) and the number of heavy-duty buses from 6.427 units (2014) to 8.479 units (2015). According to the research conducted by Hafiyah et. al, 2011, 70\% fo car owners only owned one car. And this paper used the data as parameter of vehicle numbers and emissions. ITDP assume that 1 unit heavy duty bus / TransJakarta equal to 85 units of passenger cars. (http://www.itdp.org). The highest percentage of vehicles in 2011 included passenger cars (47\%) and motorcycles (39\%). The percentage of expected vehicles in 2021 is from passenger cars (26\%) and motorcycles $(55 \%)$.

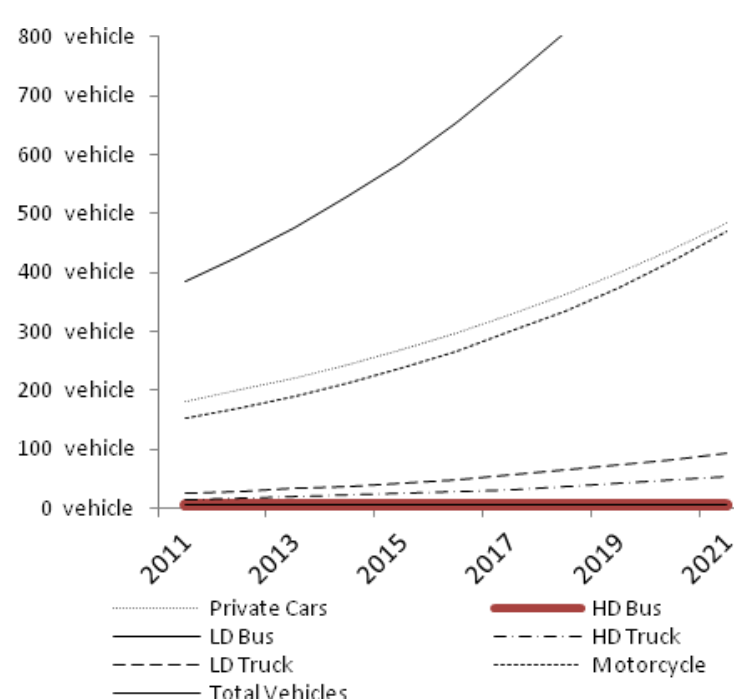

(a)

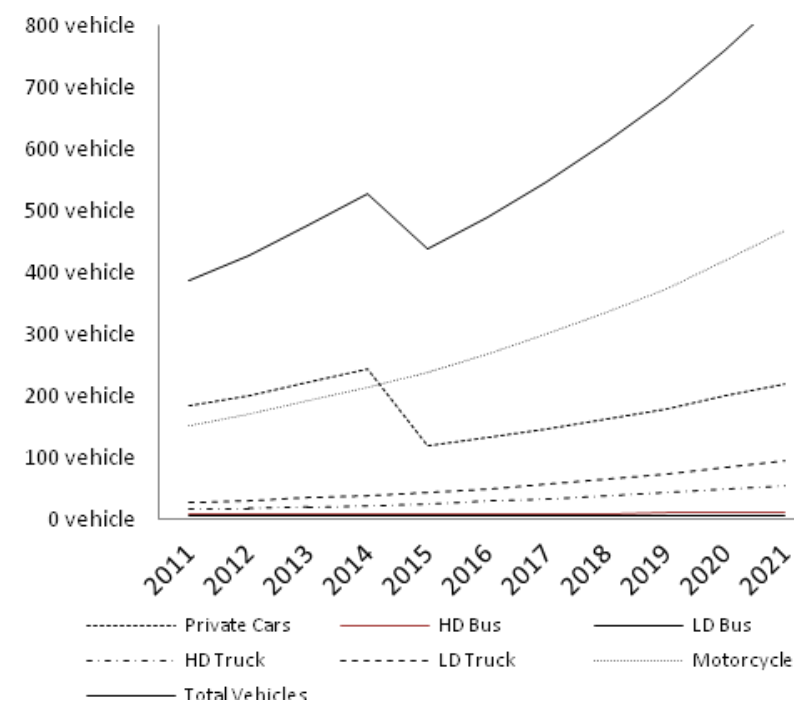

(b)

Figure 6 Number of: (a) vehicle with BAU Scenario; (b) vehicle with intention scenario (vertical scale to be multiplied by 1000)

Table 7 Vehicle fleet with Intention Scenario: weekday traffic volume in toll and non-toll roads at the Semanggi intersection

\begin{tabular}{cccccccc}
\hline Intention & Passenger cars & HD Buses & LD Buses & HD Trucks & LD Trucks & Motorcycles & Total \\
\hline 2011 & 182,082 & 6,196 & 4,531 & 14,811 & 25,800 & 152,014 & 385,434 \\
2012 & 200,809 & 6,272 & 4,587 & 16,855 & 29,360 & 170,132 & 428,014 \\
2013 & 221,463 & 6,349 & 4,643 & 19,180 & 33,411 & 190,410 & 475,455 \\
2014 & 244,240 & 6,427 & 4,700 & 21,826 & 38,020 & 213,105 & 528,319 \\
2015 & 119,086 & 8,479 & 4,757 & 24,838 & 43,266 & 238,504 & 438,931 \\
2016 & 131,900 & 8,583 & 4,816 & 28,265 & 49,236 & 266,931 & 489,731 \\
2017 & 146,092 & 8,689 & 4,875 & 32,165 & 56,029 & 298,746 & 546,597 \\
2018 & 161,812 & 8,796 & 4,935 & 36,603 & 63,760 & 334,354 & 610,259 \\
2019 & 179,222 & 8,905 & 4,995 & 41,653 & 72,557 & 374,205 & 681,537 \\
2020 & 198,506 & 9,015 & 5,056 & 47,400 & 82,568 & 418,806 & 761,351 \\
2021 & 219,865 & 9,126 & 5,118 & 53,940 & 93,961 & 468,722 & 850,733 \\
\hline
\end{tabular}

The graph compares the number of vehicles from both the BAU and Intention Scenarios (Figure 7), showing a decrease in the number of vehicles (starting in 2015) when about $68.7 \%$ of private vehicle users using the Semanggi intersection are expected to change to public 
transportation. Thus there will also be a reduction in emissions from all modes of transportation especially private vehicles.

NOx emissions from both the BAU and Intention Scenarios are shown in Figure 8a. The level of NOx emission in the BAU Scenario was 611 tons/year in 2011 and is expected to be 1,693.18 tons/year in 2021. The level of NOx emission in the Intention Scenario was 611 tons/year in 2011 and is projected to be 1,364.76 tons/year in 2021. The highest level of NOx emissions in 2011 came from passenger cars (47\%) and motorcycles (39\%). The highest level of NOx emissions in 2021 is anticipated to be from passenger cars (44\%) and motorcycle $(42 \%)$, respectively.

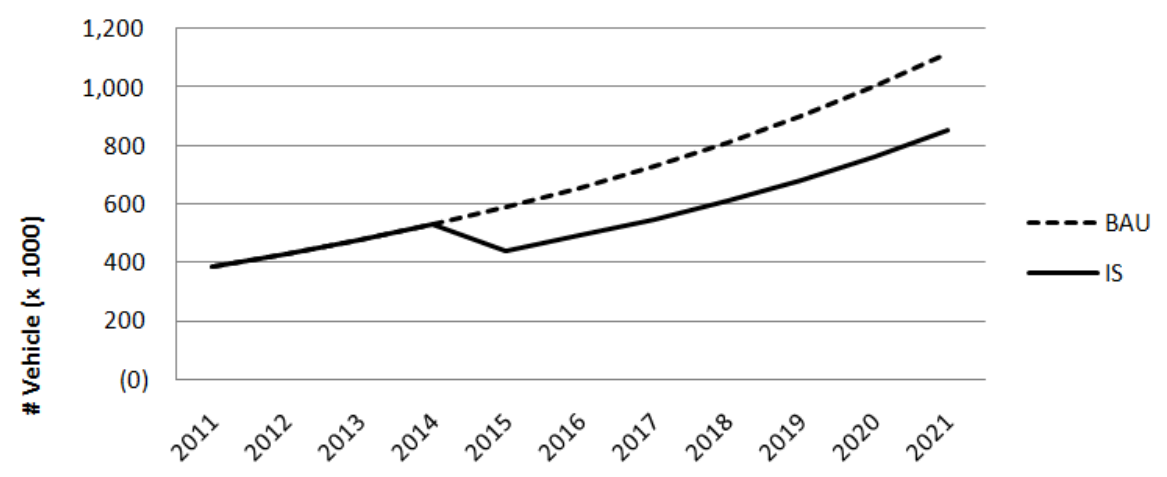

Figure 7 Comparison of number of vehicles from BAU and Intention Scenarios in toll and toll-free roads at the Semanggi intersection (weekdays)

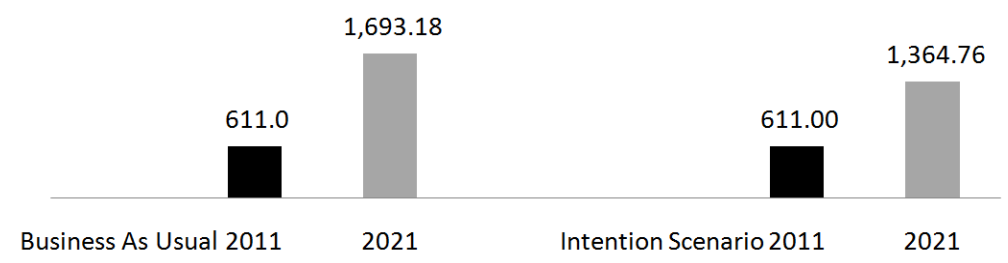

(a)

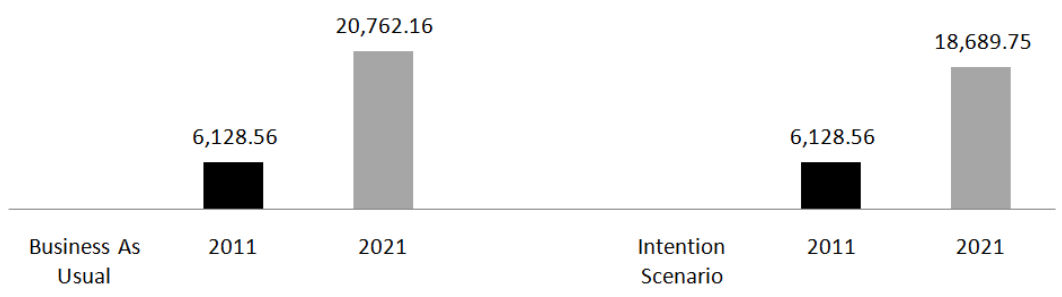

(b)

Figure 8 The level of: (a) NOx emissions reduction; (b) $\mathrm{CO}$ emissions reduction

$\mathrm{CO}$ emissions from both the BAU and the Intention Scenarios are shown in Figure $8 \mathrm{~b}$. The level of NOx emissions in the BAU Scenario was 6,128.56 tons/year in 2011 and is projected to be 20,762.16 tons/year in 2021. The level of NOx emissions in the Intention Scenario was 6.128.56 ton/year in 2011 and is expected to be 18,689.75 tons/year in 2021. The highest level of NOx emissions in 2011 was $47 \%$ from passenger cars and 39\% from motorcycles. The highest level of NOx mode share in 2021 is anticipated to be $26 \%$ from passenger cars and $55 \%$ from motorcycles.

\subsection{Model Validation}

The validation process was performed using three testing models: reproductive behavior, behavior comparison model, and sensitivity analysis. Sensitivity analysis is performed to find 
out how sensitive a variable is in affecting other variables by testing exogenous variables to measure the responses given according to real conditions. In this study, variables were tested for the vehicle fleet in the BAU Scenario. The changes in these variables were expected to be sensitive to multiple variables, such as the vehicle fleet (Figure 9). Based on the three tests, the model has been built to conform with the standards of each method, so that the policy model will be validated.

\section{CONCLUSION}

This research studied potential emissions reduction related to traffic in Jakarta, based on a case study of an intersection in Semanggi. This is the first step to studying emissions reduction on a larger scale to decrease pollution. To better understand the link between intention and action, an inverse problem could be performed: if we wanted to know the evolution of passenger car users in Semanggi intersection in 2014 (when the salient belief system was improved), then we had to estimate the ratio between "declared intention" and "real action".

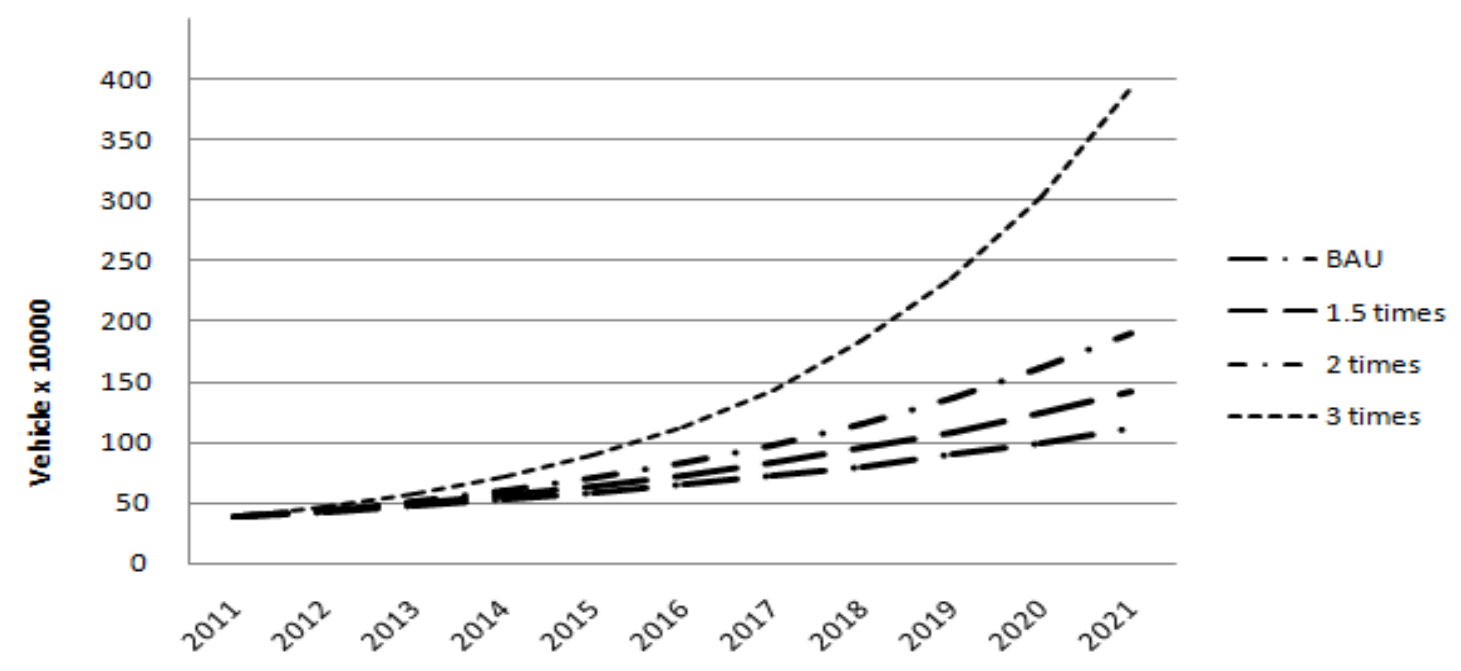

Figure 9 Sensitivity analysis

\section{REFERENCES}

Ajzen, I., 1988. Attitudes, Personality, and Behaviour. Open University Press, Milton-Keynes, England, UK; Dorsey Press, Chicago, IL, USA

Ajzen, I., 1991. The Theory of Planned Behaviour. Organizational Behaviour and Human Decision Processes, Volume 50, pp. 179-211

Hafiyah, N., Soesetyo, S.R., 2011. Explaining Commuters' Travel Behavior from Psychological Perspective: Studies of Behavioral Intention of Car Owners to Use Bus Rapid Transit in Jakarta. In: Proceedings of the $12^{\text {th }}$ International Conference on Quality in Research (QiR) 2011, Bali, Indonesia

Han, J., Hayashi, Y., 2008. A System Dynamics Model of $\mathrm{CO}_{2}$ Mitigation in China's Inter-city Passenger Transport. Transportation Research Part D, pp. 298-305

Hof, A.F., Michel, G.J., den Elzen, Roelfsema, M., 2013. The Effect of Updated Pledges and Business-as Usual Projections and New Agreed Rules on expected Global Greenhouse Gas Emissions in 2020. Environmental Science \& Policy, Volume 33, pp. 308-319

IJ-EPA, Agency for the Assesment and Application of Technology (BPPT), 2011. Data-data Traffic Survey dan Pengujian Kendaraan, 2009-2011 [unpublished] 
Lumbreras, J., Borge, R., Manuel de Andres, J., Rodriguez, E., 2015. A Model to Calculate Consistent Atmospheric Emission Projections and Its Application to Spain. Atmospheric Environment, Volume 42, pp. 5251-5266

National Police Headquarters Indonesia Traffic Corps, 2013. Repetition Data of Vehicle, Data Processed, Internal Report [unpublished]

Sterman, J.D., 2000. Business Dynamic: System Thinking and Modeling for a Complex World. Information Science Reference (an imprint of IGI Global), Hershey, PA, USA

Sugiarto, B., Soesetyo, S.R., Hafiyah, N., Syafrizal, M., Mauludi, F., Darsono, D., 2010. Studi Polusi Udara Jakarta dengan Pendekatan Intensi Masyarakat Pengguna Kendaraan Pribadi untuk Berpindah ke Bus Rapid Transit. Final Report, Hibah riset multidisiplin, DRPM Universitas Indonesia [in Bahasa]

Syafrizal, M., Bretagne, E., Hamani, N., Sugiarto, B., Moersidik, S.S., 2014. Exhaust Emissions and Behavior of Transportation Users in Jakarta: Analysis in the Case of the Semanggi intersection. In: Proceedings of the International Conference on Transport Research Arena 2014, Paris, April, France, pp. 14-17

Zhang, Q., Guojin, S., Fang, S., Tian, W., Li, X., Wang, H., 2013. Air Pollutant Emissions from Vehicles in China under Various Energy Scenarios. Science of the Total Environment, pp. 250-258

Zhao, W., Ren, H., Rotter, V.S., 2011. A System Dynamics Model for Evaluating the Alternative of Type in Construction and Demolition Waste Recycling Center-The Case of Chongqing, China. Resources. Conservation and Recycling, Volume 55, pp. 933-944 